\title{
Dietary and ethanol induced alterations of the toxikokinetics of toluene in humans
} Ewa Wigaeus Hjelm, Agneta Löf, Akio Sato, Anders Colmsjö, Bengt-Ove Lundmark,
Åke Norström
National Institute of Occupational Health, S-171 84 Solna, Sweden

E W Hjelm

A Löf

A Colmsjö

B-O Lundmark

Department of

Environmental

Health, Medical

University of

Yamanashi, Tamaho, Yamanashi 409-38,

Japan

A Sato

Department of Clinical

Pharmacology, Regional Hospital, S-901 85, Umeå, Sweden

Å Norström

Correspondence to:

E Wigaeus Hjelm, Division of Work and Environmental Physiology, National Institute of Occupational Health, S-171 84 Solna, Sweden.

Accepted for publication 5 April 1994

\begin{abstract}
This study was undertaken to evaluate the influence of a carbohydrate restricted diet, a subacute ethanol intake, and their combined effect on the kinetics of toluene in humans. Eight healthy male volunteers were exposed by inhalation at four different occasions to $200 \mathrm{mg} / \mathrm{m}^{3}$ ${ }^{2} \mathrm{H}_{8}$-toluene for two hours at a work load of $50 \mathrm{~W}$ after a one week low (30\%) carbohydrate (CH) diet or high $(60 \%)$ CH diet with ( + EtOH) or without (- EtOH) ethanol consumption (47 $\mathrm{g}$ ethanol) on the evening before exposure. Deuterium labelled toluene was used to measure the excretion of hippuric acid originating from toluene separately from hippuric acid from other sources. The results indicated that subacute ethanol consumption combined with a carbohydrate restricted diet, may enhance the metabolism of toluene in humans at an exposure concentration of $200 \mathrm{mg} / \mathrm{m}^{3}$. The cumulative amount of hippuric acid excreted in the urine up to 20 hours after the end of exposure in \% of the net uptake of toluene was enhanced by $22 \%(p=0.05)$ in the low CH + EtOH compared with the low CH-EtOH experiment. The apparent blood clearance of toluene was $37 \%$ higher in the low CH + EtOH than in the low CH-EtOH experiment, but this effect was not statistically significant $(p=0 \cdot 1)$. There were no significant changes in the kinetics of toluene as a result of a low carbohydrate diet alone. Neither did subacute ethanol intake without the combination with a carbohydrate restricted diet influence the kinetics of toluene.
\end{abstract}

(Occup Environ Med 1994;51:487-491)

Toluene is a solvent commonly used in the paint, plastics, printing, and other chemical industries. $^{1}$ Acute neurotoxic effects of toluene in humans increase in severity from mild headache at relatively low doses (50 ppm) to muscular weakness, nausea, and impaired coordination at higher doses (100 to $200 \mathrm{ppm}) .^{2}$ Reduced perceptual speed and prolonged reaction time occurred at exposure to 300 ppm, ${ }^{3}$ but not to 80 ppm. $^{4}$

The main metabolic pathway of toluene is the formation of benzyl alcohol, a reaction primarily catalysed by the microsomal cytochrome $P-450$ system. ${ }^{5}$ Further oxidation to benzaldehyde and benzoic acid is catalysed by alcohol and aldehyde dehydrogenases. Subsequently, the acid is conjugated with glycine and about $80 \%$ of the absorbed toluene is excreted in the urine as hippuric acid in humans. ${ }^{56} \mathrm{~A}$ small quantity of absorbed toluene $(<1 \%)$ is oxidised at the aromatic ring and excreted as $o$ - and $p$ - cresol in the urine..$^{7-11}$ Between $7 \%$ and $14 \%$ of the absorbed toluene is excreted unchanged by exhalation in humans. ${ }^{12}$

Many environmental factors, such as alcohol consumption, cigarette smoking, medications, exposure to environmental contaminants, and nutrition affect the metabolism of foreign compounds and are therefore likely to alter their toxicity. ${ }^{13-16}$ Such factors are important considerations in the risk assessment of compounds used industrially.

Nutritional factors are well known to influence the cytochrome $P-450$ dependent metabolism of many foreign compounds. The effects have primarily been associated with dietary protein (a high (low) protein diet increases (decreases) the enzyme activity). ${ }^{17-21}$ This association, however, was obtained from studies where the high (low) protein diets were prepared by decreasing (increasing) the carbohydrate content to make them isocaloric. Later studies showed that a low carbohydrate dietary regimen, irrespective of other nutrients, enhances the metabolism in rat liver of several industrial aromatic and chlorinated hydrocarbons..$^{22} 23$

Ethanol has both stimulating and inhibiting effects on the metabolism of foreign compounds. ${ }^{24}$ It suppresses the metabolism during or shortly after ingestion when it coexists with another foreign compound, whereas it stimulates metabolism when it has disappeared from the body. 2526

Inhibition of toluene metabolism in humans has been found during standardised short term toluene exposure after acute oral intake of ethanol. ${ }^{27}$ Chronic ethanol consumption accelerates the metabolism in rat liver of a variety of volatile hydrocabons including toluene. ${ }^{28}$ Interestingly, the effect disappeared almost completely after one day withdrawal of ethanol, suggesting that only recently ingested ethanol plays a decisive part in stimulating the enzyme activity involved in the metabolism of these hydrocarbons. 
Waldron and coworkers have shown that workers occupationally exposed to toluene who consumed ethanol regularly had lower blood toluene concentrations than workers who did not drink regularly. ${ }^{29}$

Dietary carbohydrate intake at the time of ethanol ingestion profoundly affects the metabolism stimulating effect of ethanol in rats. ${ }^{30} \mathrm{~A}$ decrease (increase) in carbohydrate intake augmented (suppressed) the effect of ethanol dose dependently. A combination of ethanol with a carbohydrate deficient diet greatly enhanced the metabolism of all the organic solvents tested. The combined effect was not merely additive as it was much greater than the sum of the effects produced by either treatment alone. The combined effect of ethanol with dietary carbohydrates has so far not been established in humans.

The aim of this study was to evaluate the influence of a low carbohydrate diet, subacute ethanol intake, and their combined effect on the kinetics of toluene in humans.

\section{Subjects, materials, and methods SUBJECTS}

Eight healthy male volunteers with an average age of 29 (range 18-42) years, and an average weight of 75 (71-90) $\mathrm{kg}$ participated in the study. The subjects were instructed to avoid work with organic solvents and not to drink any alcohol (except the predetermined amount of wine before the exposure to toluene) during the week before each exposure session. They were also instructed to refrain from taking any drugs for at least two days before exposure. The study was approved by the regional ethics committee at the Karolinska Institute, Solna, Sweden.

\section{EXPERIMENTAL DESIGN}

The volunteers were exposed on four different occasions to $200 \mathrm{mg} / \mathrm{m}^{3}$ (present Swedish permissible exposure limit, eight hour time weighted average) ${ }^{2} \mathrm{H}_{8}$-toluene (Aldrich) via inspiratory air with the aid of a valve and a mouthpiece. Deuterium labelled toluene was used to measure the excretion of hippuric acid originating from toluene separately from hippuric acid from other sources. ${ }^{31}$ Each exposure lasted for two hours. Light physical exercise (workload of $50 \mathrm{~W}$; bicycle ergometer) was undertaken during exposure. The desired toluene concentration was generated by injection of $46 \mu \mathrm{l}{ }^{2} \mathrm{H}_{8}$-toluene with a microlitre syringe into polyester laminated aluminum foil bags filled with 2001 air. After 30 minutes of equilibration the toluene concentration in the bags was analysed by gas chromatography (Perking Elmer F11; column, 3\% SE-30 on Chromosorb GAW, 1.5 $\mathrm{m}$, at $170^{\circ} \mathrm{C}$; carrier gas, nitrogen at a flow rate of $25 \mathrm{ml} / \mathrm{min}$; detector, flame ionisation). The error of the method for the determination of toluene in air was $\pm 3 \%$.

On two occasions the subjects had eaten a low carbohydrate diet (low $\mathrm{CH}$ ) consisting of $30 \%$ carbohydrates, $50 \%$ fat, and $20 \%$ protein for seven days before the exposure. At one of these occasions no alcohol was ingested the week before the exposure (low $\mathrm{CH}$ $\mathrm{EtOH}$ ), and on the other occasion the volunteers drank $47.0 \mathrm{~g}$ ethanol (one bottle of white wine, Zeller Schwarze Katze, $700 \mathrm{ml}$; ethanol content $8.5 \%$ by volume) the evening before the day of exposure (10-13 hours before the start of exposure; low $\mathrm{CH}+\mathrm{EtOH})$. At the other two exposure occasions the volunteers had eaten a moderate-high carbohydrate diet consisting of $60 \%$ carbohydrates, $25 \%$ fat, and $15 \%$ protein for seven days, on one occasion without ingestion of alcohol (high $\mathrm{CH}-$ EtOH) and on the other occasion ethanol was consumed as described previously (high $\mathrm{CH}$ $+\mathrm{EtOH})$. When alcohol was not consumed, an equicaloric amount of orange juicc was ingested in place of the wine. Both the low and high carbohydrate diet contained 2600 $\mathrm{kcal} /$ day and contained sufficient amounts of all other nutrients (protein, fat, vitamins, and minerals). The sequence of the exposure conditions was a Latin square design.

\section{TOXICOKINETIC MEASUREMENTS AND} ANALYSIS

During exposure, the exhaled air was collected from each volunteer in a polyester laminated aluminium foil bag six times each lasting for six minutes at predetermined time intervals. The expired air volume was measured in a balanced spirometer and the mean pulmonary ventilation during each sampling period was calculated. The concentration of toluene in expired air was analysed as described for the concentration in inhaled air. The net uptake of toluene during each sampling period was calculated as the difference between the total amount of solvent in the inhaled and exhaled air. The mean value of the six sampling periods was used for calculation of the cumulative net uptake during the entire exposure period.

The concentration of toluene in blood was determined before onset of the exposure and at preselected intervals during and up to 20 hours after the end of exposure. Capillary blood $(200 \mu \mathrm{l})$ was sampled from a prewarmed finger tip and collected in head space bottles with Teflon lined membranes. After equilibration with overlying air at $37^{\circ} \mathrm{C}$ for 30 minutes the head space air was analysed by gas chromatography by a head space autosampler technique (Perking Elmer F 45 with Perking Elmer LC1-100 integrator; column, $0.4 \%$ Carbowx A on Carbopack A, $2 \mathrm{~m}$, at $160^{\circ} \mathrm{C}$; carrier gas, nitrogen at a flow rate of $30 \mathrm{~m} / \mathrm{min}$; detector, flame ionisation). The toluene concentration in blood was determined from individual standard curves prepared by adding a known quantity of toluene to a known volume of blood collected before the onset of exposure. The error of the determination was $\pm 4.0 \%$ (calculated from 40 double samples in the actual concentration range).

The total amount of urine was collected immediately before exposure and up to 20 hours after exposure was ended. The concentration of deuterium labelled hippuric acid in 
urine was measured by gas chromatographymass spectrometry (GC-MS) with o-methyl hippuric acid as internal standard. Urine samples $(10 \mathrm{ml})$ were acidified to $\mathrm{pH} 1$ with concentrated $\mathrm{HCl}$ and then run through a Waters $\mathrm{C}_{18}$-Sep Pak. The Sep Pak cartridge was preeluted with $2 \mathrm{ml}$ methanol and $5 \mathrm{ml} \mathrm{H}_{2} \mathrm{O}$, and was then washed with $10 \mathrm{ml} 0.01 \mathrm{M} \mathrm{HCl}$ and $1 \mathrm{ml}$ benzene. Air was drawn through the cartridge to dryness and the sample eluted with $2.5 \mathrm{ml}$ of $\mathrm{CHCl}_{3}$ (containing $1 \%$ acetic acid). The $\mathrm{CHCl}_{3}$ fraction was evaporated to dryness, redissolved in $1 \mathrm{ml}$ methanol, and esterfied with $1 \mathrm{ml}$ of $\mathrm{CHCl}_{3} / \mathrm{SOCl}_{2}(90 / 10)$ for 30 minutes. After evaporation the ester was redissolved in $2 \mathrm{ml}$ of ethyl acetate and analysed by GC-MS.

The mass spectrometric analysis was performed with a Finnigan MAT INCOS 50 GC-MS system equipped with a Varian 3400 gas chromatograph. A capillary column, CPSil $8 \mathrm{CB}, 24 \mathrm{~m} \times 0.25 \mathrm{~mm}$ (inner diameter) with $0.13 \mu \mathrm{m}$ phase was used with helium as the carrier gas, linear velocity $27 \mathrm{~cm} / \mathrm{s}$. The sample $(1 \mu \mathrm{l})$ was injected in split mode at $230^{\circ} \mathrm{C}$ and the column was operated at $180^{\circ} \mathrm{C}$. The retention times were: hippuric acid methyl ester (1) $3 \cdot 4$, its deuterated form (2) $3 \cdot 4$, and o-methyl hippuric acid methyl ester (3) 4.1 minutes. Six ions were monitored (selected ion monitoring), with a total scan time of $0.31 \mathrm{~s}$. Only the base peaks were used for measurement; for (1) $\mathrm{m} / \mathrm{z} 105$, (2) $\mathrm{m} / \mathrm{z} 110$, and (3) $\mathrm{m} / \mathrm{z} 119$. The measurement was performed with the Lab Data System for chromatography (ELDS) after converting the data files from the INCOS 50 computer. Samples containing $0,0 \cdot 5,1,2$, or $4 \mathrm{~g} / 1$ of hippuric acid and $1 \mathrm{~g} / 1$ o-methyl hippuric acid were used to make the calibration curve.

\section{KINETIC CALCULATIONS}

The relative uptake $(R)$ of toluene (relation between the net amount absorbed and inhaled amount during the respective sampling periods) was calculated from the formula $\mathrm{R}(\%)=$ $100\left(C_{i n}-C_{e x}\right) / C_{i n}$ where $C_{\text {in }}$ and $C_{\text {ex }}$ are the toluene concentrations in inhaled and exhaled air respectively. The average relative uptake during the entire exposure period was calculated as the mean of the six sampling periods. The rate of net uptake (U) was calculated

Table 1 Toxicokinetic variables for toluene in volunteers who inhaled $200 \mathrm{mg} / \mathrm{m}^{3}$ deuterium labelled toluene for two hours performing $50 \mathrm{~W}$ physical activity after one week assignment to low (30\%) carbohydrate (CH) diet or high (60\%) CH diet with ( $+E t O H)$ or without $(-E t O H)$ ethanol consumption on the evening before the exposure

\begin{tabular}{|c|c|c|c|c|}
\hline & $\begin{array}{l}\text { Low } \\
\mathrm{CH}-\mathrm{EtOH}\end{array}$ & $\begin{array}{l}\text { Low } \\
\mathrm{CH}\end{array}$ & $\begin{array}{l}\text { High } \\
\mathrm{CH}-\mathrm{Et} \mathrm{OH}\end{array}$ & $\begin{array}{l}H i g h \\
\mathrm{CH}+\mathrm{EtOH}\end{array}$ \\
\hline $\begin{array}{l}\mathrm{C}_{\text {in }}\left(\mathrm{mg} / \mathrm{m}^{3}\right) \\
\mathrm{V}_{\mathrm{E}}(\mathrm{l} / \mathrm{min}) \\
\mathrm{R}(\%) \\
\mathrm{U}(\mathrm{mmol}) \\
\mathrm{Cl}_{\text {app }}\left(1 \cdot \mathrm{kg}^{-1} \mathrm{~h}^{-1}\right) \\
\mathrm{HA}_{\text {cum }}\left(\mathrm{mmol}^{2}\right) \\
\mathrm{HA}_{\text {cum }}(\% \text { of } \mathrm{U})\end{array}$ & $\begin{array}{l}197(2) \\
24.4(3.3) \\
48 \cdot 6(2.5) \\
2 \cdot 45(0.43) \\
0.90(2 \cdot 20) \\
1.75(0.30) \\
69 \cdot 1(12 \cdot 4)\end{array}$ & $\begin{array}{l}194(4) \\
23 \cdot 8(3 \cdot 1) \\
50 \cdot 4(3 \cdot 4) \\
2 \cdot 26(0 \cdot 48) \\
1.23(0 \cdot 50) \\
1.86(0 \cdot 25) \\
84 \cdot 3(17 \cdot 6)\end{array}$ & $\begin{array}{l}194(1) \\
23.9(3 \cdot 2) \\
49 \cdot 2(4 \cdot 8) \\
2 \cdot 24(0 \cdot 18) \\
0.93(0 \cdot 24) \\
1 \cdot 75(0.31) \\
78 \cdot 2(13.0)\end{array}$ & $\begin{array}{l}193(6) \\
24 \cdot 7(3 \cdot 1) \\
48 \cdot 6(5 \cdot 2) \\
2 \cdot 17(0 \cdot 24) \\
1 \cdot 00(0 \cdot 22) \\
1 \cdot 71(0 \cdot 22) \\
79 \cdot 3(8 \cdot 7)\end{array}$ \\
\hline
\end{tabular}

$\mathrm{C}_{\mathrm{in}}=$ toluene concentration in inhaled air; $\mathrm{V}_{\mathrm{E}}=$ pulmonary ventilation; $\mathrm{R}=$ relative uptake as expressed by $R=100\left(C_{i n}-C_{e x}\right) / C_{i n} ; U=$ cumulative net uptake as expressed by $U=V$ $\left(\mathrm{C}_{\mathrm{in}}-\mathrm{C}_{\mathrm{ex}}\right) \mathrm{t}$, where $\mathrm{t}$ is the exposure time (120 minutes); $\mathrm{Cl}_{\mathrm{app}}$, apparent clearance as expressed by $\mathrm{Cl}_{\text {app }}=\mathrm{UxAUC}^{-1} \times \mathrm{BW}^{-1}$, where AUC is the area under the blood concentration $v$ time curve and $\mathrm{BW}$ the body weight; $\mathrm{HA}_{\text {cum }}=$ cumulative amount of deuterium labelled hippuric acid excreted in the urine. Values are the mean (SD) of eight subjects. according to the equation $\mathrm{U}(\mu \mathrm{mol} / \mathrm{min})=\mathrm{V}_{\mathrm{E}}$ $\left(C_{i n}-C_{e x}\right) / t$ where $V_{E}$ is the volume of expired air during the sampling time, $t$. The cumulative net uptake during the entire exposure was calculated as the mean rate of net uptake multiplied by the exposure time (120 minutes).

Semilogarithmic plots of the toluene concentration in blood $v$ time during the elimination period were treated by the methods of residuals. Linear phases were distinguished by best fit. The half life of each phase was calculated by linear regression of the log linear blood concentration $v$ time curve with the later phase(s) subtracted.

Apparent blood clearance $\left(\mathrm{Cl}_{\text {app }}\right)$ was calculated as the quotient between the cumulative net uptake (dose) and the area under the blood concentration $v$ time curve (AUC) and adjusted for body weight. ${ }^{13}$ The AUC was calculated by the trapezoidal rule until the last blood sample was collected ( 20 hours after the end of exposure). The AUC from the last blood sampling to infinity was determined as the quotient between the line estimate of the toluene concentration in blood at the time of the last blood sampling and the slope of the last phase calculated by linear regression of the log linear blood concentration-time curve.

\section{STATISTICS}

The results are, unless otherwise stated, represented as mean values (SD). A paired Student's $t$ test was used for statistical analysis and the 0.05 level of probability was chosen as the criterion of significance (two tailed test).

\section{Results}

The cumulative net uptake of toluene during the two hour exposure ranged between $2 \cdot 2$ and $2.4 \mathrm{mmol}$ in different experimental situations. The relative uptake represented about $50 \%$ of the amount supplied, and no significant differences were found in relative uptake between the different diets (table 1).

The concentration of toluene in blood rose rapidly after the onset of exposure (fig 1A, B). The toluene concentration in blood during exposure was somewhat lower when the subjects had consumed ethanol with either the low or high carbohydrate diet compared with the concentration when the subjects had taken the same diets without ethanol (on average $8 \%$ and $7 \%$ respectively, for the last blood sample), but the corresponding total uptake was also lower ( $8 \%$ and 3\% respectively).

After exposure had ended, three elimination phases were distinguished for toluene in blood: the initial phase $(a)$ lasted $0-30 \mathrm{~min}$ utes; the rapid elimination phase $(\beta)$ lasted 31-240 minutes; and the slow elimination phase $(\gamma)$ lasted 241-1200 minutes (table 2). No significant differences in elimination rates between the diets (low $\mathrm{CH}$ and high $\mathrm{CH}$; with and without ethanol) could be found.

The apparent blood clearance was on average $37 \%$ higher after the low $\mathrm{CH}+$ EtOH diet compared with low $\mathrm{CH}-\mathrm{EtOH}$, but the difference was not significant $(p=0 \cdot 1$; table 1). 
Figure 1 Toluene concentration in capillary blood of volunteers who deuterium labelled toluene $50 \mathrm{~W}$ physical activity after one week assignment to low (30\%) carbohydrate $(\mathrm{CH}) \operatorname{diet}(A)$ or high (60\%) $\mathrm{CH}$ diet (B) with $(+E t O H)$ or without (-EtOH) ethanol consumption on the evening before the exposure. Mean (SD) values (eight subjects) are given. inhaled $200 \mathrm{mg} / \mathrm{m}^{3}$ for two hours performing

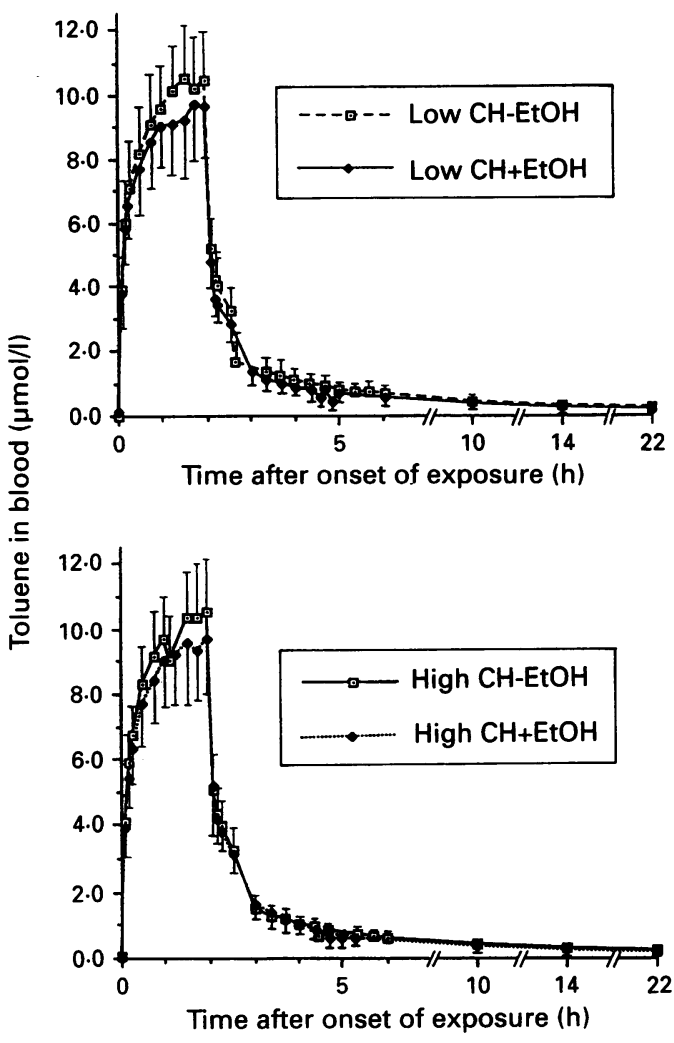

After all different experimental situations, the excretion rate of deuterium labelled hippuric acid was highest, about $5 \mu \mathrm{mol} / \mathrm{min}$, in the sample taken immediately after termination of exposure (fig 2). The half life was about 5.6 hours after all diets (table 2). The cumulative urinary excretion of deuterium labelled hippuric acid up to 20 hours after the end of exposure amounted to between $69 \%$ and $84 \%$ of the inhaled dose in the different experiments, and was significantly higher after the low $\mathrm{CH}+\mathrm{EtOH}$ than in the low $\mathrm{CH}-$ EtOH experiment $(p=0.05)$ (table 1$)$.

\section{Discussion}

The results indicated that subacute ethanol consumption combined with a carbohydrate restricted diet, may enhance the toluene metabolism in humans at an exposure to 200 $\mathrm{mg} / \mathrm{m}^{3}$ toluene with a work load of $50 \mathrm{~W}$. A carbohydrate restricted diet alone, however, had no influence on the kinetics of toluene. Similarly a subacute ethanol intake without a

Table 2 Half lives of toluene in the blood and hippuric acid in the urine of volunteers who inhaled $200 \mathrm{mg} / \mathrm{m}^{3}$ deuterium labelled toluene for two hours performing $50 \mathrm{~W}$ physical activity after one week assignment to low (30\%) carbohydrate $(\mathrm{CH})$ diet or high $(60 \%)$ $\mathrm{CH}$ diet with $(+\mathrm{EtOH})$ or without $(-E t O H)$ ethanol consumption on the evening before the exposure

\begin{tabular}{|c|c|c|c|c|}
\hline & \multicolumn{4}{|c|}{ Half life (min) } \\
\hline & $\stackrel{\text { Low }}{\mathrm{CH}-\mathrm{Et} O H}$ & $\stackrel{L o w}{C H}+E t O H$ & $\begin{array}{l}\text { High } \\
\mathrm{CH}-\mathrm{Et} O H\end{array}$ & $\begin{array}{l}\text { High } \\
\mathrm{CH}+\mathrm{EtOH}\end{array}$ \\
\hline $\begin{array}{l}\text { Toluene in blood: } \\
a(0-30 \mathrm{~min}) \\
\beta(31-240 \mathrm{~min}) \\
\gamma(241-1200 \mathrm{~min}) \\
\text { Hippuric acid in urine: }\end{array}$ & $\begin{array}{c}3 \cdot 1(1 \cdot 7) \\
44(12) \\
942(689)\end{array}$ & $\begin{array}{c}3 \cdot 3(1 \cdot 6) \\
48(16) \\
609(360)\end{array}$ & $\begin{array}{c}3 \cdot 2(1 \cdot 2) \\
40(7) \\
738(395)\end{array}$ & $\begin{array}{c}3 \cdot 3(1 \cdot 3) \\
53(20) \\
658(290)\end{array}$ \\
\hline$a(0-1200 \mathrm{~min})$ & $341(83)$ & $337(76)$ & $338(85)$ & $333(75)$ \\
\hline
\end{tabular}

Values are the mean $(\mathrm{SD})$ of eight subjects.

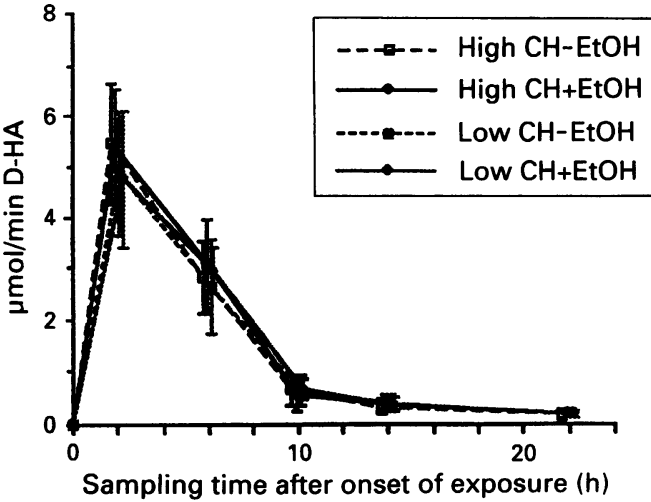

Figure 2 Excretion rate of deuterium labelled hippuric acid (D-HA) in volunteers who inhaled $200 \mathrm{mg} / \mathrm{m}^{3}$ deuterium labelled toluene for two hours performing $50 \mathrm{~W}$ physical activity after one week assignment to low (30\%) carbohydrate $(\mathrm{CH})$ diet or high $(60 \%) \mathrm{CH}$ diet with $(+E t O H)$ or without $(-E t O H)$ ethanol consumption on the evening preceding the exposure. Mean (SD) values (eight subjects) are given.

carbohydrate restricted diet did not influence the kinetics of toluene significantly.

The lack of effects of the carbohydrate restricted diet alone, and subacute intake of ethanol alone, is not in accordance with findings in rats where a low carbohydrate diet alone as well as a subacute ethanol intake alone enhance the metabolism of toluene and other volatile hydrocarbons. ${ }^{22} 2325$ There are several possible explantions for the lack of these effects in the present investigation. One reason may be that at the low level of toluene exposure used enzyme induction, if any, was not fully reflected in the in vivo metabolism of toluene. When the exposure concentration is low, hepatic metabolism of foreign chemicals is often rate limited by the hepatic blood flow independently of the enzyme capacity. ${ }^{13}{ }^{14} \mathrm{At}$ low dose, highly metabolised substrates such as toluene are completely metabolised while passing through the hepatic tissue (perfusion limited metabolism). This is especially true with metabolism under the influence of enzyme induction. Another reason possibly contributing to the lack of effects after a carbohydrate restricted diet, may be that the carbohydrate restriction was not severe enough. The low carbohydrate diet was the most extreme composition that could be tolerated for a whole week without pronounced effects on wellbeing and mental performance ( $E$ Ikkala (nutritionist), personal communication). In a rat study where a significant difference of $43 \%$ in the metabolism of toluene between low and moderate-high carbohydrate diets was found the ratio of carbohydrate content between the two diets was almost 1:6, compared with $1: 2$ in the present study. ${ }^{23}$ One contributing reason for the lack of effect, after subacute ethanol intake without carbohydrate restriction, may be that the amount of ethanol $(0.63 \mathrm{~g} / \mathrm{kg}$ on average) ingested $10-13$ hours before exposure was too small to significantly induce the unique form of cytochrome $P-450$ $(P-450 I I E 1)$, which has been characterised by its high affinity for volatile organic compounds including toluene. ${ }^{32}$ In a previous 
study with rats a single dose of ethanol (4 $\mathrm{g} / \mathrm{kg}$ ) given orally by gavage $8-18$ hours before toluene exposure definitely increased the metabolism of toluene. ${ }^{25}$

Consumption of one bottle of wine (containing $47.0 \mathrm{~g}$ ethanol) on the previous evening caused no dramatic changes in the toxicokinetics of toluene. There was some indication, however, that ethanol ingested 10-13 hours before exposure, in combination with a carbohydrate restricted diet, may enhance the metabolism of toluene. The cumulative amount of urinary hippuric acid, up to 20 hours after the end of exposure, in \% of the toluene net uptake was significantly enhanced by $22 \%(p=0.05)$ in the low $\mathrm{CH}$ $+\mathrm{EtOH}$ experiment compared with the low $\mathrm{CH}-\mathrm{EtOH}$ experiment. This effect of ethanol was not found in the high $\mathrm{CH}+$ EtOH experiment. The apparent clearance value was $37 \%$ higher, although not statistically significant $(p=0 \cdot 1)$, after the low $\mathrm{CH}+$ $\mathrm{EtOH}$ than the low $\mathrm{CH}-\mathrm{EtOH}$ experiment. The apparent clearance values calculated in this study may slightly overestimate the true metabolic clearance of toluene as it includes clearance by exhalation after termination of exposure and also redistribution in fatty tissues. The true effect of a low $\mathrm{CH}+\mathrm{EtOH}$ diet on the metabolism may therefore have been higher than the differences in apparent blood clearance indicated.

In conclusion, one bottle of light wine ( $8.5 \%$ by volume) on the evening before a work shift, especially in combination with low carbohydrate intake, may enhance the metabolism of toluene at exposure concentrations of around $200 \mathrm{mg} / \mathrm{m}^{3}$ and a work load of $50 \mathrm{~W}$.

We are grateful to Ms L Ernstgård, Ms E Gullstrand, and Ms E Hansson Risberg for skilful technical assistance.

1 Fishbein L. An overview of environmental and toxicologica aspects of aromatic hydrocarbons. II Toluene. Sci Total Environ 1985;42:267-88.

2 Oettingen WFv, Neal PA, Donahue DD. The toxicity and potential dangers of toluene. $\mathcal{F} A M A$ 1942;118:579-84

3 Gamberale F, Hultengren M. Toluene exposure: II psychophysiological functions. Work Environ Health 1972;9. 131-9.

4 Anshelm Olson B, Gamberale F, Iregren A. Coexposure to toluene and p-xylene in man: central nervous functions. Br ₹Ind Med 1985;42:117-22.

5 Gillette JR. Side chain oxidation of alkyl substituted ring compounds. F Biol Chem 1959;234:139-43.

6 Antti-Poika M, Kalliokoski P, Hänninen O. Toluene. In Snyder R, ed. Ethel Browning's toxicity and metabolism of Snyder R, ed. Ethel Browning's toxicity and metabolism of
industrial solvents vol 1. Amsterdam: Elsevier, 1987: industrial

7 Andersson R, Carlsson A, Byfailt Nordqvist M, Sollenberg J Urinary excretion of hippuric acid and $o$-cresol after laboratory exposure of humans to toluene. Int Arch Occup Environ Health 1983;53:101-8.
8 Angerer J. Occupational chronic exposure to organic solvents. VII. Metabolism of toluene in man. Int Arch vents. VII. Metabolism of toluene

9 Bakke OM, Scheline RR. Hydroxylation of aromatic hydrocarbons in the rat. Toxicol Appl Pharmacol 1970; 16:691-700.

10 Pfäfli P, Savolainen H, Kalliomäki PL, Kalliokoski P. Urinary $o$-cresol in toluene exposure. Scand $\mathcal{f}$ Work Environ Health 1979;5:286-9.

11 Woiwode W, Wodarz R, Drysch K, Weichardt $H$ Metabolism of toluene in man: gas-chromatographic determination of $\alpha-, m-$, and $p$-cresol in urine. Arch Toxicol 1979;43:93-8.

12 Carlsson A. Exposure to toluene: Uptake, distribution and elimination. Scand $\mathcal{F}$ Work Environ Health 1982;8:43-55.

13 Rowland M, Tozer TN. Clinical pharmacokinetics: concepts and applications Philadelphia: Lea and Febiger, 1980

14 Sato A. Confounding factors in biological monitoring of exposure to organic solvents. Int Arch Occup Environ Health 1993;65:561-7.

15 Wigaeus Hjelm E, Näslund PH, Wallén M. Influence of cigarette smoking on the toxicokinetics of toluene in humans. F Toxicol Environ Health 1988;25:155-163.

16 Löf $A, W$ allén $M$, Wigaeus Hjelm $E$. Influence of paracetamol and acetylsalicylic acid on the toxicokinetics of toluene. Pharmacol Toxicol 1990;66:138-41.

17 McLean AEM, McLean EK. The effect of diet and 1,1, 1-trichloro-2,2-bis(p-chlorophenyl) ethane (DDT) on microsomal hydroxylating enzymes and on sensitivity of rats to carbon tetrachloride poisoning. Biochem $\mathcal{F} 1966$; 100:564-71.

18 Seawright AA, McLean AEM. The effect of diet on carbon tetrachloride metabolism. Biochem f 1967;105:1055-60.

19 Kato R, Oshima T, Tomizawa S. Toxicity and metabolism of drugs in relation to dietary protein. $\mathcal{F p n} \mathcal{F}$ Pharmacol 1968;18:356-66.

20 Mgbodile MUK, Campbell TC. Effect of protein deprivation of male weanling rats on the kinetics of hepatic microsomal enzyme activity. $\mathcal{f}$ Nutr 1972;102:53-60.

21 Paine AJ, Mc Lean AEM. The effect of dietary protein and fat on the activity of aryl hydrocarbon hydroxylase in rat liver, kidney and lung. Biochem Pharmacol 1973;22. 2875-80.

22 Nakajima T, Koyama Y, Sato A. Dietary modification of metabolism and toxicity of chemical substances-with special reference to carbohydrate. Biochem Pharmacol 1982;31:1005-11.

23 Sato hydrocarbons in rat liver following food deprivation, hydrocarbons in rat liver following food deprivation, ethanol, phenobarbital, polychlorinated biphenyl and 3ethanol, phenobarbital, polychlorinated biphenyl and 3methylcholanthr

24 Ioannides C, Parke DV. The effect of ethanol administration on drug oxidations and possible mechanism of ethanol-barbiturate interactions. Biochem Soc Trans 1973;1:716-20.

25 Sato A, Nakajima T, Koyama Y. Dose-related effects of a single dose of ethanol on the metabolism in rat liver of some aromatic and chlorinated hydrocarbons. Toxicol Appl Pharmacol 1981;60:8-15.

26 Sato A, Nakajima T. Pharmacokinetics of organic solvent vapors in relation to their toxicity: Scand $\mathcal{F}$ Work Environ vapors in relation to

27 Wallén $\mathbf{M}$, Näslund $\mathbf{P H}$, Byfält Nordqvist $M$. The effects of ethanol on the kinetics of toluene in man. Toxicol Appl Pharmacol 1984;76:414-9.

28 Sato A, Nakajima T, Koyama Y. Effects of chronic ethanol consumption on hepatic metabolism of aromatic and chlorinated hydrocarbons in rats. $\mathrm{Br} \mathcal{F}$ Ind Med 1980 37:382-6.

29 Waldron HA, Cherry N, Johnston JD. The effects of ethanol on blood toluene concentrations. Int Arch Occup Environ Health 1983;51:365-9.

30 Sato $A$, Nakajima $T$, Koyama $Y$. Interaction between ethanol and carbohydrate on the metabolism in rat liver of aromatic and chlorinated hydrocarbons. Toxicol Appl Pharmacol 1983;68:242-9.

31 World Health Organisation. Benzoic acid and its potassium and sodium salts. Food Additive Series. Geneva: WHO, 1973;5:34-42.

32 Nakajima T, Wang R-S, Elovaara E, Park SS, Gelboin HV, Hietanen E, Vainio H. Monoclonal antibodydirected characterization of cytochrome $\mathrm{P450}$ isozymes responsible for toluene metabolism in rat liver. Biochem Pharmacol 1991;41:395-404. 